\title{
Are dictatorships less redistributive? A comparative analysis of social spending in Europe, 1950-1980
}

\author{
SERGIO ESPUELAS
}

Universitat de Barcelona

sergio.espuelas@ub.edu

\begin{abstract}
Using new data on Spain and Portugal 1950-1980, this paper shows that non-democratic governments were less generous in providing social protection and also financed their meager social policy in a less redistributive way. This contradicts recent studies that hold that dictatorships have no significant effect on social policy. The analysis also reveals that, rather than provoking a 'race to the bottom' or an increase in social spending, globalization favored the adoption of tax-funded systems instead of systems based on compulsory social security contributions.
\end{abstract}

\section{Introduction}

How do dictatorships impact social spending? Lindert (2004) showed that the extension of voting rights raised social spending. And Hicks (1999) argues that leftist parties favor the development of social policy. On this basis, we would expect dictatorships to reduce social spending, because they suppress voting rights and ban labor unions and leftist parties. Mulligan et al. (2010), however, maintain that politics is not decisive, and that aging populations and growing incomes are the key factors explaining rising social spending. Similarly, Cutler and Johnson (2004) suggest that dictatorships may use social policy to achieve political legitimacy, so they can be as redistributive as democracies.

However, most studies of the welfare state have focused on affluent democracies, probably due to the scarcity of data for non-democratic countries. For example, Flora (1986) and OECD (1985), two of the most important databases for post-World War II, have no data on dictatorships. This paper provides new evidence on social spending in Spain and Portugal 1950-80, in order to analyze Mediterranean dictatorships' impact on social spending. Along with Spain and Portugal (under dictators for most of that period), my panel dataset is composed of Greece (with a shorter period of dictatorship), and twelve European countries that remained democratic during the whole time-period. The 
econometric analysis shows that dictatorships reduced social spending, especially on more redistributive programs such as unemployment, education or health-care.

In addition to total expenditure, the paper also analyses the way in which social spending was financed, by using the ratio of social security contributions to social spending as an indicator of redistribution. The econometric results show that dictatorships financed social policy via higher social security contributions, which did not involve redistribution through government budgets. The analysis of the socialcontributions-to-social-spending ratio also reveals that globalization favored the adoption of tax-funded systems instead of social-contributions-based systems.

\section{Theories of the Welfare State}

Early studies of social spending emphasized the role played by industrialization, growing incomes, and ageing populations (Kerr et al. 1964; Wilensky 1975; Pampel and Williamson 1989). More recent studies still consider that economic growth and the ageing of population are the key explanatory variables of the evolution of social policy, while political factors are presumed to be much less important (Mulligan and Sala-iMartin 1999; Mulligan et al. 2010). Lindert (1994, 2004), however, holds that the extension of voting rights before 1930 increased social spending. Lower-income groups became more important in the political process, so support for redistribution increased. Voting turnout also increased social spending (Lindert 1996, 2004). Higher voter turnout typically reflects an increase in participation by lower-income groups (Iversen 2001), which shifts the political center of gravity left (Piven and Cloward 1994).

Median voter models also consider political factors to be important. According to these models, inequality increases redistribution, because when the median voter income is below the average income, the majority will be more willing to support redistribution (Persson and Tabellini 1994; Alesina and Rodrik 1994). Kristov et al. (1992), however, suggest that inequality can have the opposite effect. Political participation is lower among the poor. Therefore, if inequality makes poverty rates rise, those willing to support redistribution will be excluded from the political process. Finally, according to the so-called 'power-resource' theory, social policy is a working-class instrument to 
modify the market income distribution. Therefore, labor unions and leftists parties are considered crucial for social policy developments (Korpi 1983; Hicks 1999).

None of these theories are in principle applicable to non-democratic contexts. However, since they emphasize the role of democratic institutions, they implicitly suggest that the welfare state is less likely under dictatorships. The reason is straightforward. Neither the median voter nor the lower-income groups or the leftist parties will influence the political process without elections. Nonetheless, there are theories suggesting that dictatorships might also favour the welfare state. For example, for theories where the evolution of social policy is mainly driven by the ageing of population and economic growth, there will be no significant differences between democratic and non-democratic governments (Mulligan et al. 2010). Even admitting the role of politics, Cutler and Johnson (2004) consider that dictatorships encourage social policy developments in order to legitimate themselves. The classical example is Bismarck's social policy, explicitly oriented at attracting working class' support. Cutler and Johnson (2004) also suggest that dictatorships provide social protection in a different way. Authoritarian regimes are more likely to introduce insurance-based programs, instead of mean-tested programs. Therefore, the effect of democracy and dictatorship on social policy is unresolved.

Globalization's effect has also attracted attention. Some predict globalization to reduce social spending. Increasing international capital mobility should compel lower taxes and public revenues, and a 'race to the bottom' (Gordon 1983; Wildasin 1988; Mishra 1999). Rodrik (1997), however, suggests that increasing economic instability provoked by international trade exposure, creates higher demands for social protection. Huberman and Lewchuk (2003), for example, found that before World War I social protection programs were more extensive in more open economies.

Epifani and Gancia (2009), meanwhile, find trade openness correlates positively with government consumption expenditure, but trade openness is unconnected with social transfers. As an alternative to Rodrik's demand-for-insurance argument, they hold that more open economies tend to have bigger governments (only) if they export differentiated goods (that is, if their elasticity of substitution between domestic and foreign goods is low) because this allows them to benefit from a terms-of-trade 
externality that shifts part of the cost of taxation abroad. Finally, Brady et al. (2005) argue globalization had no effect on the welfare state, and maintain that domestic political and economic factors are all that matter.

\section{Social spending and dictatorships (1950-78)}

\subsection{Sources and estimates}

To assess dictatorships' impact on social policy I have collected data on social spending in fifteen European countries over the time-period 1950-78. My sample is composed of three countries which experience dictatorship for at least some of these years - Spain, Portugal and Greece - plus twelve European democracies (Sweden, Norway, Ireland, Netherlands, Finland, Belgium, Denmark, Austria, United Kingdom, Italy, France and Germany).

Data for 1950-59 is from Flora (1986), while for 1960-78 it comes from the OECD (1985). ${ }^{1}$ In both datasets social spending is broken down by program, so it has been classified into five categories: Pensions, including expenditures on old-age, survivors and disability benefits, Health-care, Welfare, including maternity-leave and sickness-leave, and family allowances, Unemployment, and Education. The analysis of social spending in a disaggregated way helps shed light on the redistribution debate. More redistributive countries will have higher levels of social spending, but also spend more in more redistributive programs, such as unemployment.

Flora (1986) and OECD (1985), however, do not report data on non-democratic governments. Only Greece is included in the OECD dataset. Therefore, I have estimated social spending levels in Spain and Portugal from primary sources. The statistical yearbooks of Portugal provide detailed information on social security and government expenditures. Before 1962, however, they only detail total social spending not its distribution among different items. Therefore, social-security-spending categorization before 1962 is based on Pereirinha and Carolo (2007). Data on Portuguese health-care expenditures between 1970 and 1978 come from the OECD health data (www.oecd.org/health/healthdata), and public spending on education from Valerio 
(2001). For Spain, social spending has been estimated from public budgets, and the reports of the Spanish National Institute of Social Insurance (Instituto Nacional de Previsión). Education spending is from Comín and Díaz (2005), who provide information on central government's spending, complemented with information on other public organizations (Organismos Autónomos) from public budget sources. ${ }^{2}$

\subsection{Social legislation and social spending trends}

Table 1 shows the new estimates for Spain and Portugal along with the available figures for Greece plus six selected European countries. Democratic countries experienced a rapid growth in social spending after World War II. In the dictatorships a basic social safety net had already been established in Greece when the military coup occurred in 1967. The Social Insurance Organization (IKA), which provided workmen's compensation, health insurance and old-age, invalidity and survivor pensions, was established in 1937. Unemployment compensation was introduced in 1945, and family allowances in 1959. The Agricultural Insurance Organization (OGA) extended healthcare and old-age pensions to farmers in 1961. Consequently, in 1962, Greek social spending differed little from that of Ireland. No major changes occurred during the Military Junta (1967-73). Greek social policy continued to be insurance-based (instead of universalistic), and assistance for large families was approved in 1972. However, as is shown in table 1, social spending stagnated until the end of the dictatorship (Petmesidou 2006; Alogoskoufis 1995).

\section{[Table 1]}

Spain and Portugal both suffered longer periods of authoritarian rule than Greece (which were inspired by conservative and fascist ideologies), that exerted bigger influences on social policy developments. In Spain, a meager social safety net (including workmen's compensation, old-age, maternity-leave and unemployment benefits) existed when Franco rose to power. There was also a consensus in favor of insurance-based schemes as opposed to means-tested programs. Consequently, social insurance expanded under Franco. Family allowances, health insurance, and professional-diseases insurance were introduced in 1938, 1942-44 and 1947 respectively. Unemployment 
insurance, however, was abolished in the 1940 os and only reestablished in 1961 (Comin 1996; Cuesta 2008).

In parallel to the 'Bismarckian' system, the government developed the so-called Mutualismo Laboral. Formally, it consisted in a number of mutual-aid associations managed and financed by employers and employees. However, in practice, the Mutualismo Laboral was tightely regulated by the State (supervising and setting benefits levels, qualifying conditions, etc.). It was almost a social-insurance system, although fragmented at the industry level and even at the firm level (Calle 1994; Guillén 1992). Despite these social legislation developments, social spending remained considerably below the European average during the 1950s and 1960s. In 1962, social spending in Spain was only $4.0 \%$ of GDP, whereas in Italy and Ireland it was, respectively, $17.4 \%$ and 12.0\% of GDP (table 1). In 1967 the 'Bismarckian' social insurances and the Mutualismo Laboral were integrated into a single, simplified, social security system. Social spending grew rapidly from the mid-1960s onwards (table 1). This occurred long before the advent of democracy, and coinciding with a period of rapid economic growth. However, social benefits continued to be wage-related and mainly financed through employers and employees' contributions. Only during the transition to democracy did public subsidies to social security increase significantly, thanks to the 1977 tax reform (Bandrés 1999; Comin 1996; Guillén 1992).

In Portugal, at the 1926 coup d'état, workmen's compensation was the only social program (besides traditional poor relief). Inspired by the idea of 'corporativism', Salazar's government promoted social protection funds within the 'corporatist' organisms in 1935.3 These funds were financed and (formally) managed by employers and employees, although they were closely regulated by the State. At first, they were voluntary, but achievements were very limited (in 1942 there were only 79,000 insured). Consequently, the State itself began creating social protection funds in the 1940s. The resultant system was close to a compulsory-social-insurance system, but fragmented at the firm or industry level, as with the Spanish Mutualismo Laboral (Lucena 2000; Cardoso and Rocha 2003). However, as in Spain, social spending during the 1950s and 1960s remained far below European norms (table 1). 
In 1962, social protection funds were centralized. A unified pensions fund (responsible for old-age, invalidity and survivors benefits) and a unified professionaldisease fund were established. Similarly, maternity, health and family-allowances funds were established at a district level. That reorganization caused the convergence of local benefits, and gave rise to the so-called 'general regime' (regime geral da previdência). During Marcelo Caetano's rule (1968-1974), social protection was extended to rural workers, domestic service and temporary laborers (Guibentief 2000; Lucena 2000). Consequently, social spending grew rapidly from the mid-1960s (table 1). Finally, shortly after the Carnation Revolution new social programs were introduced. Unemployment compensation and mean-tested pensions were established in 1975 and 1977 respectively, and a universalistic health-care system was created in 1979, making Portuguese social policy more redistributive (Esping-Andersen 1993; Pereirinha and Carolo 2007; Lopes 2005). Nonetheless, social spending in both Spain and Portugal was still below the European average in 1978.

At first glance the effect of dictatorship does not seem obvious. Social spending in Spain and Portugal were very low at the beginning of the period, but grew rapidly even before the advent of democracy. Was social spending in the 1950s and 1960s low because Spain and Portugal were dictatorships? Or was it because they were poor? Would social spending have grown faster had Spain and Portugal been democracies? To answer these questions a formal econometric analysis is carried out below.

\section{The determinants of public social spending (1950-78)}

\subsection{The variables}

Following the theoretical framework of Lindert (2004), economic, demographic and political variables, as well as the impact of globalization are included in the econometric test. The dependent variable is public social spending as a share of GDP. I analyze both total social spending and its main components: pensions, health-care, welfare, unemployment and education spending. Among the explanatory variables are the log of GDP per capita (in 1990 international Geary-Khamis dollars, from Maddison) and the GDP growth rate. ${ }^{4}$ The expected sign on GDP per capita is positive. The GDP 
growth rate captures the impact of the economic cycle, but the expected sign is less clear. Economic crises increase demands for social protection, but also reduce public revenues. The share of population over 65 years old is also included, with an expected positive sign. In analyzing education spending, I include the share of the population between 5 and 14 years old, instead of the percentage over 65 . The data-source is United Nations' World Population Prospects (http://esa.un.org/unpp/).

To assess the impact of dictatorship, I use a variable which ranges from zero to one. If country suffered a dictatorship during all the preceding four years this variable is one. When it suffered a dictatorship for three, two or one years, it takes the values 0.75 , 0.5, and 0.25 respectively. If there was democracy for the last four years it is zero. 5 Countries were classified as democratic or non-democratic according to the Polity-IV project (www.systemicpeace.org/polity/polity4.htm), which offers several indicators of democracy and autocracy. One of them is the Polity2 indicator, where countries are ranked from +10 (strongly democratic) to -10 (strongly autocratic). In our sample the non-democratic countries are Greece, from 1967 to 1973, Spain until 1977, and Portugal until 1974. The expected sign of this variable is not clear. Some theories consider that dictatorships hamper the development of the welfare state, while others consider that they have no effect.

The impact of dictatorships' political instability is also considered in the model. The expected sign of this variable is positive. Unstable dictatorships would try to increase political support by increasing social spending. Political instability is measured by the number of executive adjustments in non-democratic governments during the preceding four years (from Taylor and Jodice (1983)). Finally, the impact of globalization is measured through trade openness, defined as exports plus imports divided by GDP. The data-source is the Penn World Tables 6.2, and, again, the expected sign is unclear. There is no consensus on globalization effect.

\subsection{Discussion}

The econometric results are shown in table 2. The estimation method is weighted least squares in order to correct for (country-fixed) heteroskedasticity, adjusted for first 
order serial correlation. Our panel data-set is the 15 aforementioned countries across 8 four-year intervals 1950-1978. The benchmark years are: 1950, 1954, 1958, 1962, 1966, 1970, 1974, and 1978. All regressions include cross-country fixed-effects. Regressions reported in table $2 \mathrm{~b}$ also include time fixed-effects. In all regressions the R-squared is above 0.94. The model fits well the evolution of public social spending.

[Table 2a-2b]

The log of GDP per capita and the share of population over 65 have a positive and significant effect on most types of social spending. However, that positive effect disappears when we control for time fixed-effects. ${ }^{6}$ This suggests that both the GDP per capita and the ageing of population were (partially) capturing the effect of the passage of time. Surprisingly, after we control for time effects, the elderly do not show any positive and significant influence on pensions. In contrast, the share of kids between 5 and 14 years old has a positive and statistically significant effect on education spending, even controlling for fixed-effects.

The GDP growth rate has a negative effect on most types of social spending, and the unemployment rate has a highly significant positive effect on unemployment spending. Social spending is counter-cycle. In contrast, trade openness' effect is less clear. Rodrik's hypothesis only finds weak empirical support in the case of unemployment spending. Pensions and education, however, are reduced by trade openness. This is not surprising because unemployment is more clearly linked to (potentially) economic instability provoked by globalization. Nonetheless, when we control for time fixed-effects, trade openness' positive effect on unemployment vanishes; and trade openness' effect becomes negative and significant in the cases of welfare and total social spending also.

For political variables, our results differ from those of Mulligan et al. (2010). As table 2 shows, dictatorships reduced most types of public social spending, even controlling for time fixed-effects. ${ }^{7}$ This negative effect is particularly significant in the cases of unemployment, health and education spending, the more redistributive types of social spending. Arguably, dictatorships lowered demands for redistribution, by restricting the voice of pro-social-spending groups. Potentially dictatorships also limited 
the voice of anti-social-spending groups. But our results suggest that, even in that case, dictatorships maintained the status quo, preventing the rise of social spending. Furthermore, although everyone's voting rights were suppressed, anti-social-spending groups held more political power than pro-social-spending ones.

In Spain, for instance, free unions and other working-class organizations were banned by Franco, and many members were arrested or killed. In contrast, employers' and landowners' organizations remained legal. They could freely associate and even act as a pressure group (Molinero and Ysas 1993, 1998; Cabrera and Del Rey 2002). Some landowners and businessmen were members of government throughout the dictatorship. Actually, these two social groups, plus high-ranking civil-servants, the Catholic Church, the army, the monarchic groups and the Falange were the main political elites during Franco's dictatorship (Jerez 1996). Similarly, under Salazar's regime free unions were prohibited in Portugal (Barreto 1990, 1994), while higher-income groups were better represented in government. During the Estado Novo era no minister or civil servant was a member of a former working-class organization. Portuguese ministers in that period were mainly high-ranking civil-servants (lawyers or engineers) and military officers. There were also some landowners and businessmen. Moreover, especially during the early years of the dictatorship, many of the Portuguese ministers were conservatives, coming from catholic or monarchists groups. This situation contrasts with the government composition after the Carnation Revolution and the advent of democracy in Portugal, when the number of middle-ranking civil-servants and members of labor organizations in government increased significantly (Pinto and Almeida 2002).

The only type of social spending without statistical differences between democratic and non-democratic governments is welfare. This is not surprising though. Dictatorships were as generous as democracies in welfare spending because they prioritized family-support spending (table 3). This is a very interesting feature of Mediterranean dictatorships, which might be explained by two factors. Lynch (2006), for example, considers that pro-natalist fascist policy in Italy explains the rise of family allowances during Mussolini's rule. This argument probably applies to Spain and Portugal too, although pro-natalist ideologies also existed in democratic countries, such as France. Secondly, Pereirinha et al. (2007) hold that (rather than an instrument of Salazar's demographic policy) family allowances were designed to complement the male- 
wage. Family allowances were, therefore, an anti-poverty measure, but also an antifeminist policy aimed at keeping women out of the labor market (the objective was to guarantee that the male-wage could

maintain the whole family).

[table 3]

Finally, the 'political legitimacy' hypothesis does not find empirical support. If the 'political legitimacy' theories were right, dictatorships should not reduce social spending. However, the 'political legitimacy' theory in a softer version, finds some empirical support. As table 2 shows, dictatorships' political instability, proxied by the number of government changes, has a positive and significant effect on education and unemployment spending. And if we control for time-effects then the impact of political instability becomes significant in the cases of health and total social spending also. Nondemocratic governments tried to buy political stability by increasing social spending, but only when they faced social pressure from below and felt politically threatened.

\section{Explaining differences in social spending}

Besides statistical significance, it is interesting to analyze how big dictatorships' impact was. Spain and Portugal were non-democratic countries, but they were also poorer and younger countries. Which forces played the biggest role in explaining differences in social spending between these countries and the rest of Europe?

Table 4 shows the observed and the predicted differences in total social spending between Spain and other European countries (France, Italy, Ireland, plus the simple European average and the population-weighted European average) in 1974. This table also reports each variable's contribution to those differences. Calculations have been made from regressions 6 and 12 in table $2 .{ }^{8}$ Most of the differences in social spending between Spain and other European countries were driven by political factors. The variable 'dictatorships' explains more than $40 \%$ of that difference, and up to $60 \%$ in the case of the comparison with Ireland. This means that dictatorships' impact was not only statistically significant but also large. Political instability also played an important role, 
although in the opposite way. It provoked a 5-15\% reduction in social spending differences between Spain and the comparison countries. However, that reduction is far from enough to compensate dictatorships' negative effect. Even if we accept that (politically unstable) dictatorships tried to find political support by increasing social spending, the suppression of democratic institutions had a much bigger negative effect.

[table 4a-4b]

The ageing of population and level of GDP per capita explain much of the differences between Spain and wealthier countries, such as France, Italy or the European average. Unsurprisingly, these variables play are less important in explaining the differences between Spain and countries with similar incomes, as Ireland. However, after we control for time-effects these variables operate in the opposite direction (they now reduce the distance to wealthier, instead of increasing it). Therefore, the role played by population ageing and income levels is ambiguous. The importance of the trade openness varies. It explains only a small share of the difference between Spain and less open economies such as France or Italy (3-7\%). But it explains a bigger share of the difference between Spain and more open economies such as Ireland (13.6\%-32\%).

\section{The determinants of social spending funding (1951-79)}

\subsection{Hypotheses}

As a complement to the spending-side analysis, in this section, I carry out an alternative test for redistribution based on the financing of social spending. According to the OECD, social protection programs 'financed by compulsory employer and employee contributions to social insurance funds are, by convention, considered public' (2007, p. 8). This means that public social spending is basically funded by compulsory social security contributions plus government subsidies. 9 Therefore, we can assume that redistribution through public budgets is bigger in countries where compulsory social contributions are lower, and consequently government subsidies (that is taxpayers' contributions) are bigger. 
Social contributions do not seem to involve redistribution from employers to employees either. Though social contributions are formally paid both by employers and employees, in the long run they are taxes on wages, and employers take them as a labor cost. The cost of social protection in countries where social contributions are high is paid by wage-earners. Finally, contributory systems do not seem to involve more redistribution among employees either. Unlike mean-tested or universalistic systems, social benefits in contributory systems are usually wage-related. Consequently, the ratio of social contributions to social spending seems to be a good indicator of (lower) redistribution.

Here, that ratio is used to assess the redistributive impact of dictatorships, complementing the spending-side-only analysis of the previous sections. If dictatorships are less redistributive than democracies then the ratio of social contributions to social spending should be higher in dictatorships. Thanks to the OECD national accounts records, we have detailed information on social security contributions collected by the state in several OECD countries since 1950. The ratio of compulsory social contributions to social spending is calculated by dividing social contributions each year by social spending in the same year. The difference between social spending and social contributions is assumed to be financed via public subsidies.

\section{[Graph 1]}

Graph 1 shows social contributions relative to social spending in four selected European countries between 1950 and 1981. The differences between countries were large, and were unchanged or even widened over time. This suggests that the evolution of social contributions is path-dependent: once social programs are introduced and the financing-style is established no big changes occur. Thus, to analyze its determinants it seems convenient to look at the early welfare state. To some extent this is what EspingAndersen (1990) did. He identified three distinct welfare state regimes in terms of their political origins: the conservative or continental model, the social-democratic or Scandinavian model, and the liberal or Anglo-American model. The social-democratic model is the most generous and redistributive. The conservative model is also generous but less redistributive. Social benefits there are high but wage-related, reproducing market inequalities. Finally, social protection in liberal countries is less generous. They 
rely on market mechanisms to provide insurance. However, liberal social programs tend to be mean-tested, instead of wage-related programs, so they echo market income distribution less than the conservative models. Therefore, from Esping-Andersen's theory, one would initially expect the ratio of social contributions to social spending to be higher in the conservative countries.

Botero et al. (2004), meanwhile, suggest that employment regulation, collective bargaining laws and social security systems are determined by legal traditions. Countries in the French civil-law-tradition regulate labor markets more extensively than the English-common-law countries, which preserve the freedom of contract to a greater extent. Though Botero et al. do not explicitly theorize on the determinants of social contributions, it is plausible to assume that compulsory social-security contributions imply more labor market regulation and less freedom of contract. Therefore, I would expect the ratio of social contributions to social spending to be higher in the French-civillaw countries.

On a slightly different note, Cutler and Johnson (2004) find that catholic countries are more likely to create earnings-related schemes. However, they offer no theoretical explanation of this behavior. Therefore, we expect social contributions to be higher in catholic countries, but given the lack of a clear theoretical link, one should be careful when interpreting the role of religion. Qualitative studies on the political economy of social policy have also reserved a role for globalization. According to Baldwin (1990) export-oriented farmers in Denmark opposed insurance-based systems, because compulsory social-security contributions implied higher labor costs. Similarly, Ullman (1981) maintains that German export-oriented firms (together with smaller and laborintensive firms) opposed Bismarck's social-insurance laws in 1880s. Finally, Haggard and Kaufman (2008) suggest that protectionist countries (like Latin American ones during the 1960-70s) tended to create contributory social-security systems. Despite the implied higher labor costs, such systems had weak business opposition. The reason is that firms faced no international competition, so they could transfer social security costs to final prices. In contrast, more open economies were less prone to accept contributory systems. 
None of the previous studies focus explicitly on the determinants of social contributions. However, we can derive from them several hypotheses that help explain differences in social contributions across countries. The development strategy (exportoriented vs. protectionist), the dominant religion, Esping-Andersen's welfare regimes and legal traditions are potential determinants of social contributions. Moreover, this basic theoretical framework allows us to test dictatorships' impact.

\subsection{Empirical test}

To analyze the determinants of social contributions I use a logistic model, which allows testing the probability of having a certain social-contributions-to-social-spending ratio. The basic logistic model is given by:

$$
y_{t}=\alpha_{t}+\beta X_{i t}+\varepsilon_{t}
$$

Where $\alpha_{t}$ is the baseline hazard, $\beta$ a set of parameters and $X_{i t}$ a vector of characteristics of country $i$ in year $t$, and $y_{t}$ is a dummy variable with value 1 when the ratio of social contributions to social spending is higher or equal to 0.7 , and zero otherwise. I chose the threshold 0.7 because it allows us to test the probability a social protection system is mainly funded through social contributions. ${ }^{10}$ As mentioned before, data on social contributions comes from the OECD National Accounts. ${ }^{11}$ Among the explanatory variables I have included: the population share of Catholics and Protestants, a dummy variable for the legal tradition, and a dummy variable for the three types of Esping-Andersen's welfare capitalisms. ${ }^{12}$ Globalization is proxied by trade openness. And the impact of dictatorship is measured by a dictatorship dummy variable, defined as in section 4. Lastly, the log of GDP and the share of population over 65 are included as control variables.

\section{[Table 5]}

The estimation method is logit regressions. The panel is composed of fifteen European countries (as in previous sections) and 8 four-year intervals between 1951 and 1979.13 The benchmark years are 1951, 1955, 1959, 1963, 1967, 1971, 1975 and 1979. As table 5 shows, GDP has a positive and statistically significant impact on the probability of 
a high share of social contributions. The percentage of population over 65 , however, does not have any significant effect on the financing of social spending is. As for globalization, more open economies were less likely to adopt social protection systems financed via social contributions (and more likely to adopt tax-funded systems). Rather than provoking a 'race to the bottom' or an increase in social spending, trade openness conditioned the way social policy is financed. This is consistent with previous qualitative studies which showed that export-oriented firms tend to reject insurance-based systems because they imply higher labor costs (Ullman 1981; Baldwin 1990; Haggard and Kaufman 2008).

Religion seems to have a significant role also. Catholicism appears to encourage the adoption of contributory systems, while Protestantism seems to favor tax-funded systems. This fits Cutler and Johnson's (2004) findings. However, as said before, there is no clear theoretical link between religion and social contributions. Therefore, one should be careful when interpreting the influence of religion. As for legal traditions, Englishcommon-law countries, as well as Scandinavian countries, seem less likely to have high ratios of social contributions to social spending (and more likely to adopt tax-funded systems). In contrast, French-civil-law countries tend to rely on contributory systems. This is consistent with Botero et al.'s (2004) finding that French-civil-law countries tend to regulate labor markets more extensively than English-common-law countries. Similarly, Esping-Andersen's hypothesis finds empirical support also. Countries belonging to the "conservative model" have high ratios of social contributions to social spending. In contrast, countries in the social-democratic and the liberal models (the Scandinavian and the English-common-law countries) are prone to adopt tax-funded systems.

Finally, the dictatorship variable is associated with a high ratio of social contributions to social spending. This result holds in all five regressions in table 5, no matter what institutional variable (religious, political or legal tradition) are included. These results and those of section 4 confirm that non-democratic governments, not only were less generous in providing social protection, but also financed their meager social policy in a less redistributive way. As graph 2 shows, until approximately the mid-1960s the ratio of social contributions to social spending in both Spain and Portugal was extremely high and remained well above one. Social security revenues exceeded social 
spending, which was unknown scenario in the rest of Europe. Only after the mid-1960s did the Spanish and Portuguese ratios of social contributions to social spending converge with those of other catholic, French-law and conservative countries.

[graph 2]

\section{A Mediterranean-dictatorships model of social protection?}

As shown in section 4, social spending in Spain and Portugal remained very low due to the political repression of pro-social-spending groups. ${ }^{14}$ In such a scenario, it is not surprising that the ratio of social contributions to social spending remained high until the mid-1960s. This strategy allowed Franco's and Salazar's regimes to finance social policy with little government subsidies. In Portugal, for example, taxation levels in 1965 (excluding social contributions) were almost the same as in 1913 (12\% and $11 \%$ of GDP, respectively). Even in 1973 they were only slightly higher (13\% of GDP) (Lopes 2005). Similarly, government revenues in Spain in 1960 and 1975 were not far from those of 1913 (respectively 12\%, 12\% and $11 \%$ of GDP). ${ }^{15}$

Moreover, it seems that employers had no big incentives to oppose social contributions. Both in Spain and Portugal, workers had limited bargaining power (particularly before the 1960s). In Portugal, for example, Marcelo Caetano himself admitted that Estado Novo's collective-bargaining system was aimed at lessening workers bargaining power (Dias 2005; Barreto 1994). In this context firms were allowed to transfer social security costs to wages. In fact, during the early Franco regime, employers offered little opposition to social-insurance programs (although such opposition was bigger among small-size firms). Opposition to social reforms aimed at strengthening labor bargaining power was stronger (Molinero and Ysas 1993, 1998). In sum, until the mid-1960s social policy in Spain and Portugal was financed through social contributions, with little public subsidy. However, since employers were able to transfer social contribution costs to wages, Spanish and Portuguese workers paid themselves for most of their meager social benefits. 
Dictatorship's trade policy is also a key element. Both Spain and Portugal implemented aggressive protectionist trade policies, especially before the sixties (Confraria 2005). Trade protectionism allowed firms to transfer social security costs to final prices. This reduced employers' opposition to social contributions. Lastly, low levels of social spending before the 1960 s also explains the high social-contributions-to-socialspending ratios. If social spending had been higher, more public subsidies would have been needed to finance social policy.

The fall in the social-contributions-to-social-spending ratio, in the mid-1960s, was driven by changes in the political context. In Spain, the Collective Bargaining Act (into effect since 1961) allowed workers to negotiate working conditions with employers. Strikes remained prohibited. However, after 1963 they became a common instrument in collective bargaining (Molinero and Ysas 1998). The increase of working-class bargaining power reduced employers' ability to transfer social contributions costs to wages. Moreover, clandestine labor-unions expanded during that period; and, along with university student movements and some social-catholic groups (that supported workers' demands), became an important source of political opposition. Consequently, from the mid-1960s, and especially in the early-1970s, Franco's dictatorship faced increasing political instability (Tusell 2005), which made the ratio of social contributions to social spending fall, in the same way that it made social spending rise.

In Portugal labor disputes were not as important as in Spain. However, after Marcelo Caetano's reforms in 1969 clandestine union activities increased and strikes became more frequent (Barreto 1990). Changes in the political context seem more crucial in Portugal. As early as 1958, the presidential elections were characterized by unusual social unrest. Shortly afterwards, the beginning of the colonial war in Africa, in 1961-62, prompted protests and social turmoil in Portugal that eventually led to the fall of the Portuguese Estado Novo. Faced with this social unrest, Portuguese rulers decided, during the National Labor Conferences (Colóquios Nacionais do Trabalho), in 1960-62, to reduce social security savings and increase social benefits (Lucena 2000), causing a fall in the social-contributions-to-social-spending ratio.

Similarly, as a result of gradual trade liberalization, Spanish and Portuguese firms faced more international competition from the 1960s, so transferring social 
protection costs to prices became more difficult. Moreover, the gradual increase in social spending that occurred from the mid-1960s resulted in increasing costs. All this explains why Spanish employers complained for the first time about the cost of social contributions in the 1970s, in a context of an economic crisis, of relatively high social spending, relatively strong international competition, and intense labor disputes (Cabrera and Del Rey 2002).

In summary, political repression allowed Franco's and Salazar's dictatorships to finance their meager social policy with little government subsidies. At the same time, the limited bargaining power of laborers, together with trade protectionism, allowed firms to transfer social security costs to wages and final prices. However, changes in the political context together with increasing trade openness, made unsustainable the extremely high ratios of social contributions to social spending of the 1950 s and 1960 .

\section{Conclusions}

Using new data on Spain and Portugal 1950-1980, this paper shows that dictatorships were less generous than democracies in providing social protection, especially for more redistributive programs such as unemployment, education and healthcare. Moreover, workers themselves paid for most of their meager social benefits in non-democratic countries. These results differ from those of Mulligan et al. (2010), who maintain that dictatorships have little effects on social policy. This is probably because they include both communist and non-communist dictatorships in their wide sample of countries, whereas I only include right-wing dictatorships. As Haggard and Kaufman (2008) show, communist countries, in the post-World War II era, used to have high social spending levels. However, disentangling why social policy differed in communist and non-communists dictatorships is beyond the scope of this paper. Finally, our results also show that, rather than provoking a 'race to the bottom' or an increase in social spending, globalization conditioned the way in which social policy was financed. More open economies were more likely to rely on tax-funded systems, whereas trade protectionism favored the adoption of insurance-based systems. 
${ }^{1}$ Flora's (1986) social spending levels have been rescaled to make them equal to the OECD levels in 1960. French data over the time-period 1950-59 come from Flora (1983). A comparison between Flora's and OECD's social spending levels in 1960 is shown in the online appendix.

${ }^{2}$ For more details on the Portuguese data see the working-paper version (Espuelas 2010). More details on the Spanish data are available on request.

3 Four types of funds were stipulated by law: union funds, pensions' funds, mutual-aid funds, and civil servants funds. See Cardoso and Rocha (2003) and Lucena (2000).

4 In the analysis of unemployment spending, the GDP growth rate has been replaced by the unemployment rate (the denominator is total active population). Data-source is: OECD Annual Labor Force Statistics (http://stats.oecd.org/Index.aspx).

5 Years in which transition to democracy or military coup happened are considered half democratic and half dictatorial. For example, if a country suffered a coup in 1976, the dictatorship variable in 1978 takes value 0.625 (0.5 because that country was non-democratic during two years: 1977 and 1978, plus 0.125 because half of the year 1976 is considered dictatorial).

${ }^{6}$ The effect of GDP might be distorted because it is included both on the left side (social spending/GDP) and on the right side (GDP/population) of my specification. However, if we use 'social spending' as the dependent variable instead of 'social spending/ GDP', GDP's effect holds (see the online appendix).

7 Besides the log of GDP per capita, I have also controlled for non-linear income effects in the online appendix, and Dictatorships' negative effect holds.

${ }^{8}$ Looking at social spending by categories (education, pensions, health, unemployment and welfare), instead of total social spending, we obtain similar conclusions (see the online appendix).

9 In addition to social contributions and public subsidies some social protection programs have its own resources (receipts from assets, for example) but this does not affect our argument.

10 The average ratio of social contributions to social spending in my sample is 0.52 . Therefore, to analyse the determinants of high social-contributions-to-social-spending ratios we need to choose a threshold clearly above that value. The 0.7 threshold is a rather arbitrary choice. However, as shown in the online appendix, if we use 0.75 or 0.8 as thresholds the results hold. Moreover, I made two additional robustness-checks. Firstly, I have replicated the analysis with a linear probabilistic model, instead of a logistic model (table D.2 in the online appendix). Secondly, I performed an alternative estimation using the ratio of social contributions to social spending as the dependent variable, instead of my dichotomous dependent variable (table D.3 in the online appendix). The additional tests confirm the logit regression outcomes. 
${ }^{11}$ Most of the data comes from the 1983 edition. When necessary, data has been compiled from a different edition and social contributions have been rescaled to make them equal to the last available year in the 1983 edition. Data on Spanish social contributions in 1958-81 come from Comín and Díaz (2005), while in 195458 come from the OECD National Accounts.

12 The share of Catholics and Protestants refers to the post-World War II period and it comes from Lindert's worksheet. Countries' legal origins are taken from Botero et al. (2004) and Esping-Andersen's classification comes from Esping-Andersen (1990).

13 The time-period is $1951-79$ (instead of 1950-78) because data on social contributions in 1950 is missing for several countries.

14 This section focuses on Spain and Portugal. As shown in section 3, the Military Junta rule in Greece lasted for a short period of time and kept the pre-existing social-protection model.

15 Figures on Spanish State revenues come from Comín and Díaz (2005) -table 12.9-, GDP figures from Prados (2003). 


\section{Acknowledgements}

I thank Alfonso Herranz and Peter Lindert for valuable comments and advice. I also appreciate the comments of Jordi Catalan, Fabian Gouret, Jordi Guilera, Julio Martinez-Galarraga, Marc Prat, Javier San-Julián, the editors, two anonymous referees and the participants at the 4th Globaleuronet Summer School, the $8^{\text {th }}$ EHES Conference, the $29^{\text {th }}$ APHES Conference and the $2^{\text {nd }}$ AEHE meeting. Daniel Carolo and Adoración Alvaro shared with me unpublished data. The Centre d'Estudis Antoni de Campmany, the Spanish MEC (projects SEJ2005-02498/econ and ECO2009-13331C02-02), and the Xarxa d'Economia i Polítiques Públiques generously provided funding for this research. The usual disclaimers apply.

\section{References}

ALESINA, A. and RODRIK, D. (1994). Distributive politics and economic growth. The Quarterly Journal of Economics 109 (2), pp. 465-490.

ALOGOSKOUFIS, G. (1995). The two faces of Janus: institutions, policy regime and macroeconomic performance in Greece. Economic Policy 10 (1), pp. 149-192.

BALDWIN, P. (1990). The politics of Social Solidarity and the Bourgeois Basis of the European Welfare State, 1875-1975. Cambridge: Cambridge University Press.

BANDRÉS, E. (1999). Gasto Público y estructuras del bienestar: el sistema de protección social. In García Delgado, J. L. (dir.). España Economía: ante el siglo XXI. Madrid: Espasa Calpe.

BARRETO, J. (1990). Os primordios da Intersindical sob Marcelo Caetano. Análise Social 105-106 (XXV), pp. 57-117.

BARRETO, J. (1994). Comunistas, católicos e os sindicatos sob Salazar. Análise Social 125-126 (XXIX), pp. 287-317.

BOTERO, J., DJANKOV, S., LA PORTA, R., LOOPEZ-DE-SILANES, F. and SHLEIFER, A. (2004). The regulation of Labor. The Quarterly Journal of Economics 119 (4), pp. 1339-1382.

BRADY, D., SEELEIB-KAISER, M. and BECKFIELD, J. (2005). Economic Globalization and the Welfare State in Affluent Democracies, 1975-2001. American Sociological Review 70 (6), pp. 921-948.

CABRERA, M. and DEL REY REGUILLO, F. (2002). El poder de los empresarios: Política e intereses económicos en la España contemporánea, 187520oo. Madrid: Taurus. 
CALLE, D. de la (1994). El mutualismo laboral en el régimen de Franco. In CASTILLO, S. (ed.). Solidaridad desde abajo: trabajadores y Socorros Mutuos en la España Contemporánea. Madrid: UGT, Centros de Estudios Históricos.

CARDOSO, J. L. and ROCHA, M. M. (2003). Corporativismo e EstadoProvidência (1933-1962). Ler História 45, pp. 111-135.

COMÍN, F. (1996). Historia de hacienda pública II. España 18o8-1995. Barcelona: Crítica.

COMÍN, F. and DÍAZ, D. (2005). Sector público administrativo y Estado del Bienestar. In CARRERAS, A. and TAFUNELL, X. (coords.). Estadísticas históricas de España. Bilbao: Fundación BBVA.

CONFRARIA, J. (2005). Política económica. In Lains, P. and da Silva, F. (orgs.). História económica de Portugal, 170o-20oo. Volume III, o século XX. Lisboa: Imprensa de Ciências Sociais.

CUESTA, J. (2008). Estado y Seguros Sociales en España. El Instituto Nacional de Previsión, 191-1939. In CASTILLO, S. (dir.). Solidaridad, Seguridad, Bienestar. Cien años de protección social en España. Madrid: Ministerio de Trabajo e Inmigración.

CUTLER, D. and JOHNSON, R. (2004). The birth and growth of the social insurance state: Explaining old age and medical insurance across countries. Public Choice 120, pp. 87-121.

DIAS, J. (2005). A organizaçao do trabalho. In LAINS, P. and DA SILVA, F. (orgs.). História económica de Portugal, 1700-200o. Volume III, o século XX. Lisboa: Imprensa de Ciências Sociais.

EPIFANI, P. and GANCIA, G. (2009). Openness, Government Size and Terms of Trade. The Review of Economic Studies 76, pp. 629-668.

ESPING-ANDERSEN, G. (1990). The three worlds of welfare capitalism. Cambridge: Polity Press.

ESPING-ANDERSEN, G. (1993). Orçamentos e democracia: o EstadoProvidencia en Espanha e Portugal, 1960-1986. Análise Social 122 (XXVIII), pp. 589606.

ESPUELAS, S. (2010). The Determinants of Social Spending in Spain, 1950-80, Are Dictatorships Less Redistributive? Documents de Treball de la Facultat d'Economia i Empresa, E10/240.

FLORA, P. (1983). State, economy and society in Western Europe, 1815-1975: a data handbook in two volumes. Frankfurt: Campus, London: Macmillan, Chicago: St. James Press.

FLORA, P. (ed.) (1986). Growth to limits: the Western European Welfare States since World War II. Berlin: Walter de Gruyter. 
GORDON, R. (1983). An Optimal Taxation Approach to Fiscal Federalism. Quarterly Journal of Economics 98, pp. 567-586.

GUIBENTIEF, P. (2000). Segurança Social. In Barreto, A. and Mónica, M. F. (cords.). Diccionario de História de Portugal. Porto: Giguirinhas (9), pp. 411-413.

GUILLÉN, A. (1992). Social Policy in Spain: From Dictatorship to Democracy (1939-1982). In FERGE, Z. and KOLBERG, J. E. (eds.). Social Policy in a Changing Europe. Frankfurt: Campus Verlag.

HAGGARD, S. and KAUFMAN, R. R. (2008). Development, Democracy and Welfare States: Latin America, East Asia and Eastern Europe. Princeton and Oxford: Princeton University Press.

HESTON, A., SUMMERS, R. and ATEN, B. (2006). Penn World Table Version 6.2. Center for International Comparisons of Production, Income and Prices at the University of Pennsylvania.

HICKS, A. (1999). Social democracy and welfare capitalism: A century of income security politics. London: Cornell University Press.

HUBERMAN, M. and LEWCHUK, W. (2003). European economic integration and the labour compact, 1850-1913. European Review of Economic History 7 (1), pp. 341.

IVERSEN, T. (2001). The Dynamics of Welfare State Expansion: Trade Openness, De-Industrialization and Partisan Politics. In PIERSON, P (ed.). The New Politics of the Welfare State. Oxford: Oxford University Press.

JEREZ, A. (1996). El régimen de Franco: elite política central y redes clientelares, 1938-1957. In ROBLES, A. (coord.). Política en penumbra. Patronazgo y clientelismo políticos en la España contemporánea. Madrid: Siglo Veintiuno de España Editores.

KERR, C., DUNLOP, J., HARBISON, F. and MYERS, C. (1964). Industrialism and industrial man. New York: Oxford University Press.

KORPI, W. (1983). The democratic class struggle. London: Routledge and Keagan Paul.

KRISTOV, L., LINDERT, P. H. and McCLELLAND, R. (1992). Pressure groups and redistribution. Journal of Public Economics 48 (2), pp. 135-163.

LINDERT, P. H. (1994). The Rise of social Spending, 1880-1930. Explorations in Economic History 31, pp.1-37.

LINDERT, P. H. (1996). What limits social spending. Explorations in Economic History 33, pp.1-34. 
LINDERT, P. H. (2004). Growing public social spending and economic growth since the eighteenth century. Cambridge: Cambridge University Press.

LOPES, J. da S. (2005). Finanças públicas. In LAINS, P. and DA SILVA, F. (orgs.). História económica de Portugal, 1700-20oo. Volume III, o século XX. Lisboa: Imprensa de Ciências Sociais.

LUCENA, M. (2000). Providência Social. In BARRETO, A. and MÓNICA, M. F. (cords.). Diccionario de História de Portugal. Porto: Giguirinhas (9), pp. 411-413.

LYNCH, J. (2006). Age in the welfare state: the origins of social spending on pensioners, workers, and children. Cambridge: Cambridge University Press.

MISHRA, R. (1999). Globalization and the Welfare State. Northampton, MA: Edward Elger.

MOLINERO, C. and YSAS, P. (1993). Los industriales catalanes y el primer ventennio franquista: ¿adhesión política y disidencia económica? In SÁNCHEZ, I., ORTIZ, M. and RUIZ, D. (1993). España franquista, Causa general y actitudes sociales ante la dictadura. Albacete: Universidad Castilla La Mancha.

MOLINERO, C. and YSAS, P. (1998). Productores disciplinados y minorías subversivas. Clase obrera y conflictividad laboral en la España franquista. Madrid: Siglo XXI Editores.

MULLIGAN, C. B. and SALA-I-MARTIN, X. (1999). Gerontocracy, retirement, and social security. NBER Working Paper 7117.

MULLIGAN, C. B, GIL, R. and SALA-I-MARTIN, X. (2010). Social Security and Democracy. The B.E. Journal of Economic Analysis \& Policy 10(1), article 18.

OECD (1985). Social expenditure: 1960-1990, Problems of growth and control. Paris: OECD.

OECD (several years). National Accounts, detailed tables, volume II. Paris: OECD, Department of economics and statistics.

OECD (2007). The social expenditure database: An interpretive guide. SOCX 1980-2003 (www.stats.oecd.org).

PAMPEL, F. C. and WILLIAMSON, J. B. (1989). Age, class, politics, and the welfare state. Cambridge: Cambridge University Press.

PEREIRINHA, J. A. and CAROLO, D. (2007). O Estado-providência em Portugal: a evolução da despesa social ao longo do século XX. 27th APHES Conference.

PEREIRINHA, J. A., ARCANJO, M. and CAROLO, D. (2007). Social protection and family policy in the Portuguese corporatism: the creation and development of family allowances (abono de família) in the Estado Novo period. 27 $7^{\text {th }}$ APHES Conference. 
PERSSON, T. and TABELLINI, G. (1994). Is inequality harmful for growth? American Economic Review 84 (3), pp. 600-621.

PETMESIDOU, M. (2006). Tracking Social Protection: Origins, Path Peculiarity, Impasses and Prospects. In PETMESIDOU, M. and MOSSIALOS, E. (ed.) (2006) Social Policy Developments in Greece, Burlington; Aldershot: Ashgate.

PINTO, A. C. and ALMEIDA, P. T. de (2002). Portuguese Ministers, 1851-1999: Social Background and Paths to Power. South European Society and Politics 7 (2), pp.5-40.

PIVEN, F. F. and CLOWARD, R. A. (1994). Regulating the poor. New York: Vintage.

PRADOS, L. (2003). El progreso económico de España, 1850-20oo. Bilbao: Fundación BBVA.

RODRIK, D. (1997). Has globalization gone too far? Washington: Institute for International Economy.

TAYLOR, Ch. L. and JODICE, D. A. (1983). World Handbook of Political and Social Indicators. Binghamton, New York: Vail-Ballou Press.

TUSELL, J. (2005). Dictadura franquista y democracia, 1939-2004. Barcelona: Crítica.

ULLMAN, H. (1981). German industry and Bismarck's Social Security System. In W. J. Momsen (ed.). The emergence of the Welfare State in Britain and Germany, 1850-1950. London: Croom Helm.

VALÉRIO, N. (ed.) (2001). Estatísticas Históricas Portuguesas. Lisbon: INE.

WILDASIN, D. (1988). Nash Equilibria in Models of Fiscal Federalism. Journal of Public Economics 35, pp. 229-240.

WILENSKY, H. (1975). The welfare state and equality: Structural and ideological roots of public expenditures. Berkeley: University of California cop. 
Table 1. Social spending (as a \% of GDP) in Europe (1950-78)

\begin{tabular}{cccccccccc}
\hline \hline & Belgium & Denmark & Germany & Ireland & Italy & UK & Greece & Portugal & Spain \\
\hline 1950 & 12.57 & 12.46 & 16.63 & 10.01 & 9.39 & 12.45 & & 3.21 & 4.07 \\
1954 & 13.55 & 13.76 & 17.18 & 11.80 & 12.23 & 12.18 & & 3.78 & 3.18 \\
1958 & 15.90 & 16.49 & 20.51 & 11.60 & 15.25 & 13.71 & & 4.33 & 3.90 \\
1962 & 19.27 & 17.46 & 20.70 & 11.99 & 17.36 & 14.87 & 8.47 & 4.67 & 3.98 \\
1966 & 22.55 & 20.25 & 22.49 & 14.09 & 20.17 & 16.62 & 10.23 & 4.79 & 5.06 \\
1970 & 25.10 & 26.19 & 23.55 & 16.55 & 21.11 & 18.42 & 10.69 & 6.08 & 9.98 \\
1974 & 28.70 & 30.68 & 28.67 & 20.21 & 23.53 & 20.83 & 9.92 & 8.60 & 12.05 \\
1978 & 37.27 & 32.42 & 30.89 & 21.49 & 26.54 & 21.86 & 12.64 & 11.90 & 16.68 \\
\hline \hline
\end{tabular}

Source: see text.

Table 2a. The determinants of social spending (1950-78)

\begin{tabular}{|c|c|c|c|c|c|c|c|c|c|c|c|c|}
\hline Dep. var. (in Logs) & $\begin{array}{c}\text { Edu. } \\
(1) \\
\end{array}$ & & $\begin{array}{c}\text { Pensions } \\
\text { (2) } \\
\end{array}$ & & $\begin{array}{c}\text { Health } \\
(3) \\
\end{array}$ & & $\begin{array}{c}\text { Welfare } \\
(4) \\
\end{array}$ & & $\begin{array}{c}\text { Unemp. } \\
(5) \\
\end{array}$ & & $\begin{array}{c}\text { Total } \\
(6) \\
\end{array}$ & \\
\hline $\mathrm{C}$ & $\begin{array}{r}-6.167 \\
(1.558)\end{array}$ & $* * *$ & $\begin{array}{r}-5.729 \\
(0.955)\end{array}$ & $* * *$ & $\begin{array}{l}-9.585 \\
(0.891)\end{array}$ & $* * *$ & $\begin{array}{l}-5.083 \\
(1.227)\end{array}$ & $* * *$ & $\begin{array}{l}-7.090 \\
(1.920)\end{array}$ & $* * *$ & $\begin{array}{r}-4.534 \\
(0.855)\end{array}$ & $* * *$ \\
\hline Log(GDP per capita) & $\begin{array}{r}0.765 \\
(0.131)\end{array}$ & $* * *$ & $\begin{array}{r}0.610 \\
(0.181)\end{array}$ & $* * *$ & $\begin{array}{r}1.020 \\
(0.161)\end{array}$ & $* * *$ & $\begin{array}{r}0.536 \\
(0.240)\end{array}$ & $* *$ & $\begin{array}{r}-0.417 \\
(0.429)\end{array}$ & & $\begin{array}{r}0.575 \\
(0.149)\end{array}$ & $* * *$ \\
\hline GDP growth & $\begin{array}{r}-0.012 \\
(0.005)\end{array}$ & $* *$ & $\begin{array}{r}-0.020 \\
(0.008)\end{array}$ & $* *$ & $\begin{array}{r}-0.015 \\
(0.006)\end{array}$ & $* *$ & $\begin{array}{r}0.005 \\
(0.010)\end{array}$ & & & & $\begin{array}{r}-0.011 \\
(0.005)\end{array}$ & $* *$ \\
\hline Log(Elderly) & & & $\begin{array}{r}1.197 \\
(0.369)\end{array}$ & $* * *$ & $\begin{array}{r}0.596 \\
(0.357)\end{array}$ & * & $\begin{array}{r}0.815 \\
(0.542)\end{array}$ & & $\begin{array}{r}2.599 \\
(0.927)\end{array}$ & $* * *$ & $\begin{array}{r}1.034 \\
(0.320)\end{array}$ & $* * *$ \\
\hline Log(Kids, 5-14) & $\begin{array}{r}0.414 \\
(0.241)\end{array}$ & * & & & & & & & & & & \\
\hline Log(Openness) & $\begin{array}{r}-0.140 \\
(0.077)\end{array}$ & * & $\begin{array}{l}-0.240 \\
(0.119)\end{array}$ & $* *$ & $\begin{array}{r}0.040 \\
(0.090)\end{array}$ & & $\begin{array}{r}-0.144 \\
(0.158)\end{array}$ & & $\begin{array}{r}0.746 \\
(0.286)\end{array}$ & $* *$ & $\begin{array}{r}-0.083 \\
(0.075)\end{array}$ & \\
\hline Dictatorships & $\begin{array}{r}-0.407 \\
(0.136)\end{array}$ & $* * *$ & $\begin{array}{l}-0.465 \\
(0.251)\end{array}$ & * & $\begin{array}{r}-0.374 \\
(0.109)\end{array}$ & $* * *$ & $\begin{array}{r}0.304 \\
(0.237)\end{array}$ & & $\begin{array}{r}-1.277 \\
(0.301)\end{array}$ & $* * *$ & $\begin{array}{l}-0.389 \\
(0.144)\end{array}$ & $* * *$ \\
\hline Political instability & $\begin{array}{r}0.021 \\
(0.010)\end{array}$ & $* *$ & $\begin{array}{r}0.026 \\
(0.019)\end{array}$ & & $\begin{array}{r}0.011 \\
(0.009)\end{array}$ & & $\begin{array}{r}-0.024 \\
(0.020)\end{array}$ & & $\begin{array}{r}0.072 \\
(0.022)\end{array}$ & $* * *$ & $\begin{array}{r}0.017 \\
(0.011)\end{array}$ & \\
\hline Unemployment rate & & & & & & & & & $\begin{array}{r}0.192 \\
(0.023)\end{array}$ & $* * *$ & & \\
\hline $\begin{array}{l}\text { Country Fixed-Effects } \\
\text { Time Fixed-Effects }\end{array}$ & $\begin{array}{r}\text { yes } \\
\text { no }\end{array}$ & & $\begin{array}{r}\text { yes } \\
\text { no }\end{array}$ & & $\begin{array}{r}\text { yes } \\
\text { no }\end{array}$ & & $\begin{array}{r}\text { yes } \\
\text { no }\end{array}$ & & $\begin{array}{r}\text { yes } \\
\text { no }\end{array}$ & & $\begin{array}{r}\text { yes } \\
\text { no }\end{array}$ & \\
\hline R-squared & 0.981 & & 0.962 & & 0.977 & & 0.949 & & 0.942 & & 0.974 & \\
\hline Mean dep. var. & 1.568 & & 2.227 & & 1.503 & & 1.827 & & -1.499 & & 3.414 & \\
\hline DW & 1.889 & & 2.128 & & 2.316 & & 2.037 & & 2.283 & & 1.960 & \\
\hline Obs. & 117 & & 114 & & 112 & & 112 & & 82 & & 115 & \\
\hline
\end{tabular}

Notes: All dependent variables are GDP shares. Standard errors in brackets, ${ }^{*}$ significance at 10\% level, ${ }^{* *}$ significance at $5 \%$ level, ${ }^{* *}$ significance at $1 \%$ level. The number of observation varies from column to column because some years' data is missing. 
Table $2 \mathrm{~b}$. The determinants of social spending (1950-78)

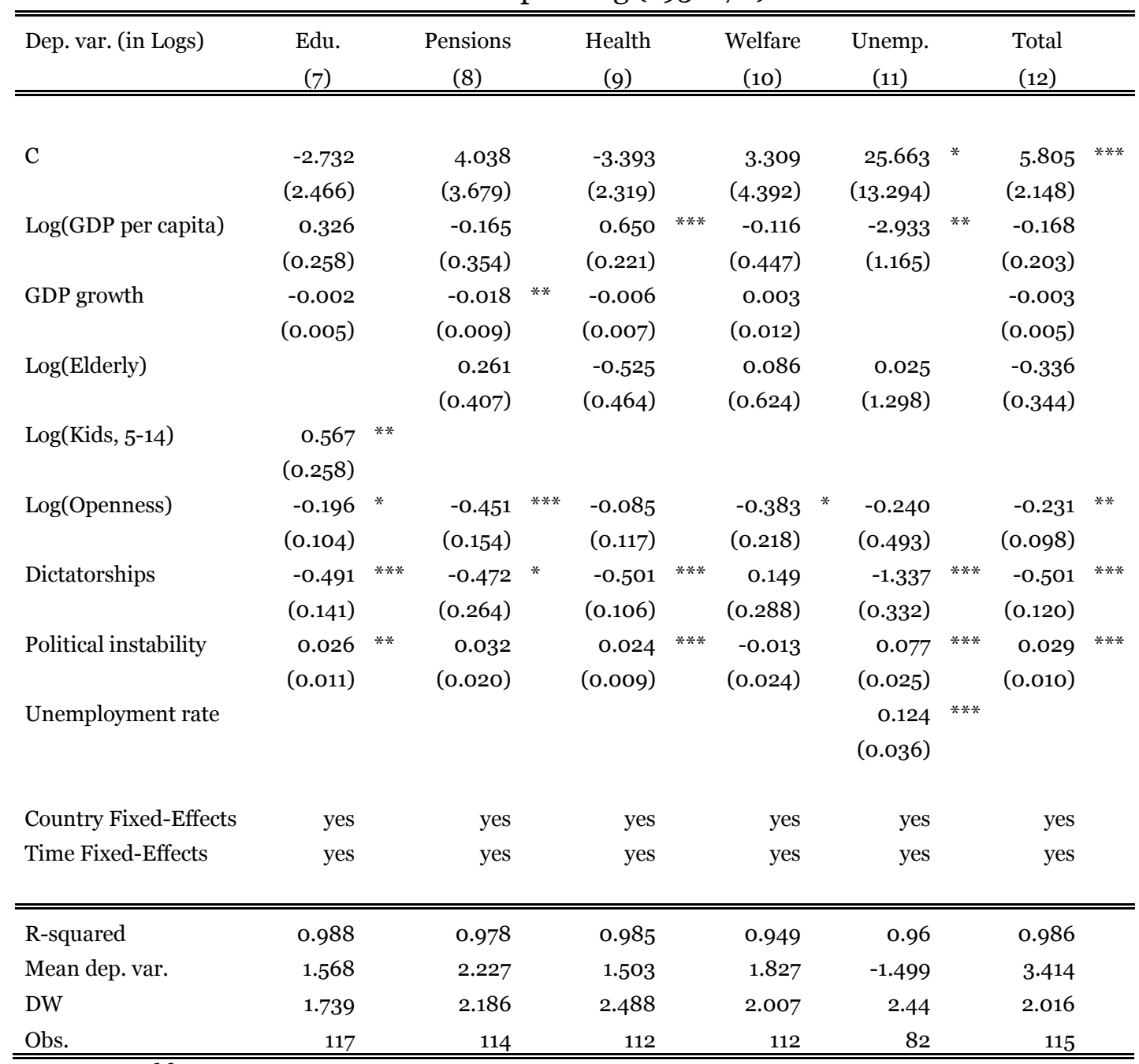

Notes: see table $2 \mathrm{a}$. 
Table 3. Family support as a \% of welfare spending (1950-78)

\begin{tabular}{lcccccccc}
\hline \hline & 1950 & 1954 & 1958 & 1962 & 1966 & 1970 & 1974 & 1978 \\
\hline France & & & & 0.64 & 0.64 & & 0.74 & \\
Sweden & 0.56 & 0.55 & 0.54 & 0.56 & 0.55 & 0.47 & 0.41 & 0.52 \\
Denmark & $0.74^{\mathrm{a}}$ & 0.76 & 0.77 & 0.84 & 0.79 & 0.76 & 0.70 & 0.58 \\
Germany & 0.06 & 0.07 & 0.12 & 0.32 & 0.40 & 0.33 & 0.24 & 0.33 \\
UK & 0.24 & 0.24 & 0.23 & 0.21 & 0.16 & 0.21 & 0.14 & \\
Ireland & 0.37 & 0.43 & 0.47 & 0.40 & 0.37 & 0.34 & 0.37 & 0.24 \\
Italy & & 0.45 & 0.45 & 0.40 & 0.45 & 0.34 & 0.32 & 0.23 \\
Austria & & $0.18^{\mathrm{b}}$ & 0.13 & 0.16 & 0.14 & 0.38 & 0.31 & 0.40 \\
Netherlands & 0.38 & 0.39 & 0.33 & 0.30 & 0.35 & 0.26 & 0.18 & 0.26 \\
Belgium & 0.35 & 0.36 & 0.37 & 0.37 & 0.35 & 0.32 & 0.27 & 0.21 \\
Portugal & 0.83 & 0.84 & 0.86 & 0.77 & 0.66 & 0.64 & 0.81 & 0.48 \\
Spain & 0.72 & 0.66 & 0.60 & 0.64 & 0.50 & 0.81 & 0.65 & 0.41 \\
\hline \hline
\end{tabular}

Sources: For Spain, own made (see text). Data on Portugal comes from Pereirinha and Carolo (2007), data on France from Flora (1983), and data on the rest of countries from Flora (1986).

Notes: Norway and Finland have been removed from the table, because their figures were not far from those of Sweden. For Greece, there is no disaggregated information.

a. In 1951.

b. In 1955 .

Table 4a. Explaining differences in total social spending (1974)

\begin{tabular}{|c|c|c|c|c|c|}
\hline & $\begin{array}{l}\text { Europe } \\
\text { (This co }\end{array}$ & $\begin{array}{c}\begin{array}{c}\text { Europe } \\
\text { (weighted) } \\
\text { ntry's level m }\end{array} \\
\end{array}$ & $\begin{array}{c}\text { Italy } \\
\text { inus Spa } \\
\end{array}$ & $\begin{array}{r}\text { France } \\
\text { s level in }\end{array}$ & $\begin{array}{l}\text { Ireland } \\
\text { 4) }\end{array}$ \\
\hline Time Fixed-Effects & No & No & No & No & No \\
\hline Country Fixed-Effects & $\begin{array}{r}0.164 \\
(21.90)\end{array}$ & $\begin{array}{r}0.164 \\
(20.10)\end{array}$ & $\begin{array}{r}0.317 \\
(33.85)\end{array}$ & $\begin{array}{r}0.117 \\
(12.44)\end{array}$ & $\begin{array}{r}0.440 \\
(68.00)\end{array}$ \\
\hline Log(GDP per capita) & $\begin{array}{r}0.177 \\
(23.57)\end{array}$ & $\begin{array}{r}0.188 \\
(23.02)\end{array}$ & $\begin{array}{r}0.175 \\
(18.68)\end{array}$ & $\begin{array}{r}0.273 \\
(28.95)\end{array}$ & $\begin{array}{r}-0.084 \\
(-12.96)\end{array}$ \\
\hline GDP growth & $\begin{array}{l}0.000 \\
(0.06)\end{array}$ & $\begin{array}{l}0.000 \\
(0.06)\end{array}$ & $\begin{array}{l}0.000 \\
(0.03)\end{array}$ & $\begin{array}{l}0.000 \\
(0.04)\end{array}$ & $\begin{array}{l}0.000 \\
(0.06)\end{array}$ \\
\hline Log(Elderly) & $\begin{array}{r}0.191 \\
(25.46)\end{array}$ & $\begin{array}{r}0.220 \\
(26.92)\end{array}$ & $\begin{array}{r}0.151 \\
(16.11)\end{array}$ & $\begin{array}{r}0.257 \\
(27.16)\end{array}$ & $\begin{array}{l}0.058 \\
(8.92)\end{array}$ \\
\hline Log(Openness) & $\begin{array}{l}-0.060 \\
(-7.95)\end{array}$ & $\begin{array}{l}-0.036 \\
(-4.42)\end{array}$ & $\begin{array}{l}-0.028 \\
(-2.94)\end{array}$ & $\begin{array}{l}-0.024 \\
(-2.58)\end{array}$ & $\begin{array}{r}-0.088 \\
(-13.58)\end{array}$ \\
\hline Dictatorships & $\begin{array}{r}0.318 \\
(42.40)\end{array}$ & $\begin{array}{r}0.333 \\
(40.76)\end{array}$ & $\begin{array}{r}0.389 \\
(41.55)\end{array}$ & $\begin{array}{r}0.389 \\
(41.18)\end{array}$ & $\begin{array}{r}0.389 \\
(60.07)\end{array}$ \\
\hline Political instability & $\begin{array}{l}-0.041 \\
(-5.43)\end{array}$ & $\begin{array}{l}-0.053 \\
(-6.43)\end{array}$ & $\begin{array}{r}-0.068 \\
(-7.27)\end{array}$ & $\begin{array}{l}-0.068 \\
(-7.20)\end{array}$ & $\begin{array}{r}-0.068 \\
(-10.51)\end{array}$ \\
\hline Predicted difference (in logs) & $\begin{array}{l}0.749 \\
(100)\end{array}$ & $\begin{array}{l}0.817 \\
(100)\end{array}$ & $\begin{array}{l}0.936 \\
(100)\end{array}$ & $\begin{array}{l}0.944 \\
(100)\end{array}$ & $\begin{array}{l}0.647 \\
(100)\end{array}$ \\
\hline Observed difference (in logs) & 0.614 & 0.644 & 0.669 & 0.660 & 0.517 \\
\hline
\end{tabular}

Notes: All variables are defined as in table 2. Each variable contribution is calculated by multiplying the coefficients from regression 6 (no time-effects) and regression 12 (time-effects) in table 2 by the independent variables values in 1974. Europe's independent variables values are just the average of the 15 European countries included in the sample. 'Europe-weighted' is a population weighted European average. Each variable contribution (in percentage) appears in brackets. 
Table 4b. Explaining differences in total social spending (1974)

\begin{tabular}{|c|c|c|c|c|c|}
\hline & Europe & $\begin{array}{c}\text { Europe } \\
\text { (weighted) }\end{array}$ & Italy & France & Ireland \\
\hline & \multicolumn{5}{|c|}{ (This country's level minus Spain's level in 1974) } \\
\hline Time Fixed-Effects & Yes & Yes & Yes & Yes & Yes \\
\hline \multirow[t]{2}{*}{ Country Fixed-Effects } & 0.848 & 0.763 & 0.852 & 0.846 & 0.611 \\
\hline & $(93.38)$ & $(87.22)$ & $(80.39)$ & $(84.63)$ & $(80.73)$ \\
\hline \multirow[t]{2}{*}{ Log(GDP per capita) } & -0.052 & -0.055 & -0.051 & -0.080 & 0.025 \\
\hline & $(-5.70)$ & $(-6.29)$ & $(-4.84)$ & $(-8.02)$ & $(3.25)$ \\
\hline \multirow[t]{2}{*}{ GDP growth } & 0.000 & 0.000 & 0.000 & 0.000 & 0.000 \\
\hline & $(0.02)$ & $(0.02)$ & (0.01) & (0.01) & $(0.02)$ \\
\hline \multirow[t]{2}{*}{ Log(Elderly) } & -0.062 & -0.071 & -0.049 & -0.083 & -0.019 \\
\hline & $(-6.83)$ & $(-8.17)$ & $(-4.63)$ & $(-8.35)$ & $(-2.48)$ \\
\hline \multirow[t]{2}{*}{ Log(Openness) } & -0.166 & -0.101 & -0.077 & -0.068 & -0.245 \\
\hline & $(-18.28)$ & $(-11.49)$ & $(-7.24)$ & $(-6.78)$ & $(-32.39)$ \\
\hline \multirow[t]{2}{*}{ Dictatorships } & 0.409 & 0.429 & 0.501 & 0.501 & 0.501 \\
\hline & $(45.07)$ & $(48.96)$ & $(47.28)$ & $(50.12)$ & $(66.24)$ \\
\hline \multirow[t]{2}{*}{ Political instability } & -0.069 & -0.090 & -0.116 & -0.116 & -0.116 \\
\hline & $(-7.65)$ & $(-10.24)$ & $(-10.97)$ & $(-11.62)$ & $(-15 \cdot 36)$ \\
\hline \multirow[t]{2}{*}{ Predicted difference (in logs) } & 0.908 & 0.875 & 1.060 & 1.000 & 0.756 \\
\hline & $(100)$ & $(100)$ & $(100)$ & $(100)$ & $(100)$ \\
\hline Observed difference (in logs) & 0.614 & 0.644 & 0.669 & 0.660 & 0.517 \\
\hline
\end{tabular}

Notes: see table 4b. 
Table 5. The determinants of (high) social contributions (1951-79)

Dependent variable: social contributions are more than $70 \%$ of social spending

\begin{tabular}{|c|c|c|c|c|c|c|c|c|c|c|}
\hline $\mathrm{C}$ & $\begin{array}{r}-32.575 \\
(13.899)\end{array}$ & $* *$ & $\begin{array}{l}-37.496 \\
(13.152)\end{array}$ & $* * *$ & $\begin{array}{r}-27.687 \\
(12.081)\end{array}$ & $* *$ & $\begin{array}{r}-34.652 \\
(16.593)\end{array}$ & $* *$ & $\begin{array}{r}-36.641 \\
(17.245)\end{array}$ & $* *$ \\
\hline Log (GDP per capita) & $\begin{array}{r}3.477 \\
(1.659)\end{array}$ & $* *$ & $\begin{array}{r}4.335 \\
(1.639)\end{array}$ & $* * *$ & $\begin{array}{r}2.013 \\
(1.347)\end{array}$ & & $\begin{array}{r}4.043 \\
(2.148)\end{array}$ & * & $\begin{array}{r}4.043 \\
(2.148)\end{array}$ & * \\
\hline Elderly & $\begin{array}{r}-0.035 \\
(0.209)\end{array}$ & & $\begin{array}{r}-0.102 \\
(0.224)\end{array}$ & & $\begin{array}{r}0.552 \\
(0.399)\end{array}$ & & $\begin{array}{r}-0.146 \\
(0.233)\end{array}$ & & $\begin{array}{r}-0.146 \\
(0.233)\end{array}$ & \\
\hline Trade openness & $\begin{array}{l}-0.048 \\
(0.025)\end{array}$ & $*$ & $\begin{array}{r}-0.045 \\
(0.023)\end{array}$ & $* *$ & $\begin{array}{r}-0.045 \\
(0.020)\end{array}$ & $* *$ & $\begin{array}{r}-0.049 \\
(0.026)\end{array}$ & * & $\begin{array}{r}-0.049 \\
(0.026)\end{array}$ & * \\
\hline Dictatorship & $\begin{array}{r}14.590 \\
(3.208)\end{array}$ & $* * *$ & $\begin{array}{r}11.896 \\
(2.168)\end{array}$ & $* * *$ & $\begin{array}{r}11.757 \\
(2.443)\end{array}$ & $* * *$ & $\begin{array}{l}12.279 \\
(2.315)\end{array}$ & $* * *$ & $\begin{array}{l}12.279 \\
(2.315)\end{array}$ & $* * *$ \\
\hline Catholicism & $\begin{array}{r}2.051 \\
(1.156)\end{array}$ & $*$ & & & & & & & & \\
\hline Protestantism & & & $\begin{array}{l}-3.207 \\
(1.521)\end{array}$ & $* *$ & & & & & & \\
\hline \multicolumn{11}{|l|}{ Legal origin } \\
\hline French & & & & & $\begin{array}{r}3.713 \\
(1.695)\end{array}$ & $* *$ & & & & \\
\hline Scandinavian \& English & & & & & & & $\begin{array}{l}-1.989 \\
(1.102)\end{array}$ & * & & \\
\hline Continental & & & & & & & & & $\begin{array}{r}1.989 \\
(1.102)\end{array}$ & * \\
\hline McFadden R-squared & 0.642 & & 0.675 & & 0.710 & & 0.638 & & 0.638 & \\
\hline Log likelihood & -20.746 & & -18.855 & & -16.816 & & -20.953 & & -20.953 & \\
\hline Obs. with dep. var. $=0$ & 87 & & 87 & & 87 & & 87 & & 87 & \\
\hline Obs. with dep. var. $=1$ & 24 & & 24 & & 24 & & 24 & & 24 & \\
\hline Total Obs. & 111 & & 111 & & 111 & & 111 & & 111 & \\
\hline
\end{tabular}

Notes: The total number of observations is not $120(15 \times 8)$ because data for some years is missing. Robust Standard errors in brackets. ${ }^{*}$ significance at $10 \%$ level, ${ }^{* *}$ significance at $5 \%$ level, ${ }^{* * *}$ significance at $1 \%$ level.

Graph 1. Social contributions in selected countries (1950-81)

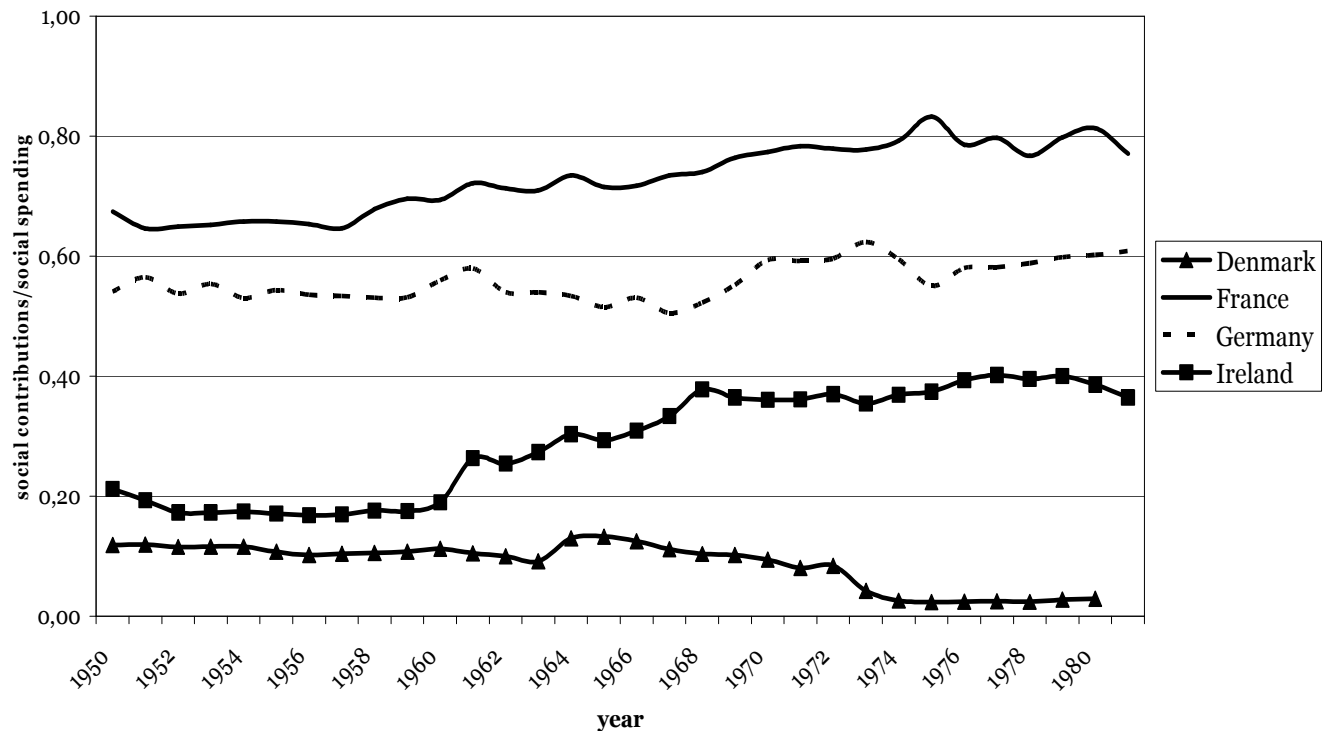

Source: see text 
Graph 2. Dictatorships and social contributions (1950-81)

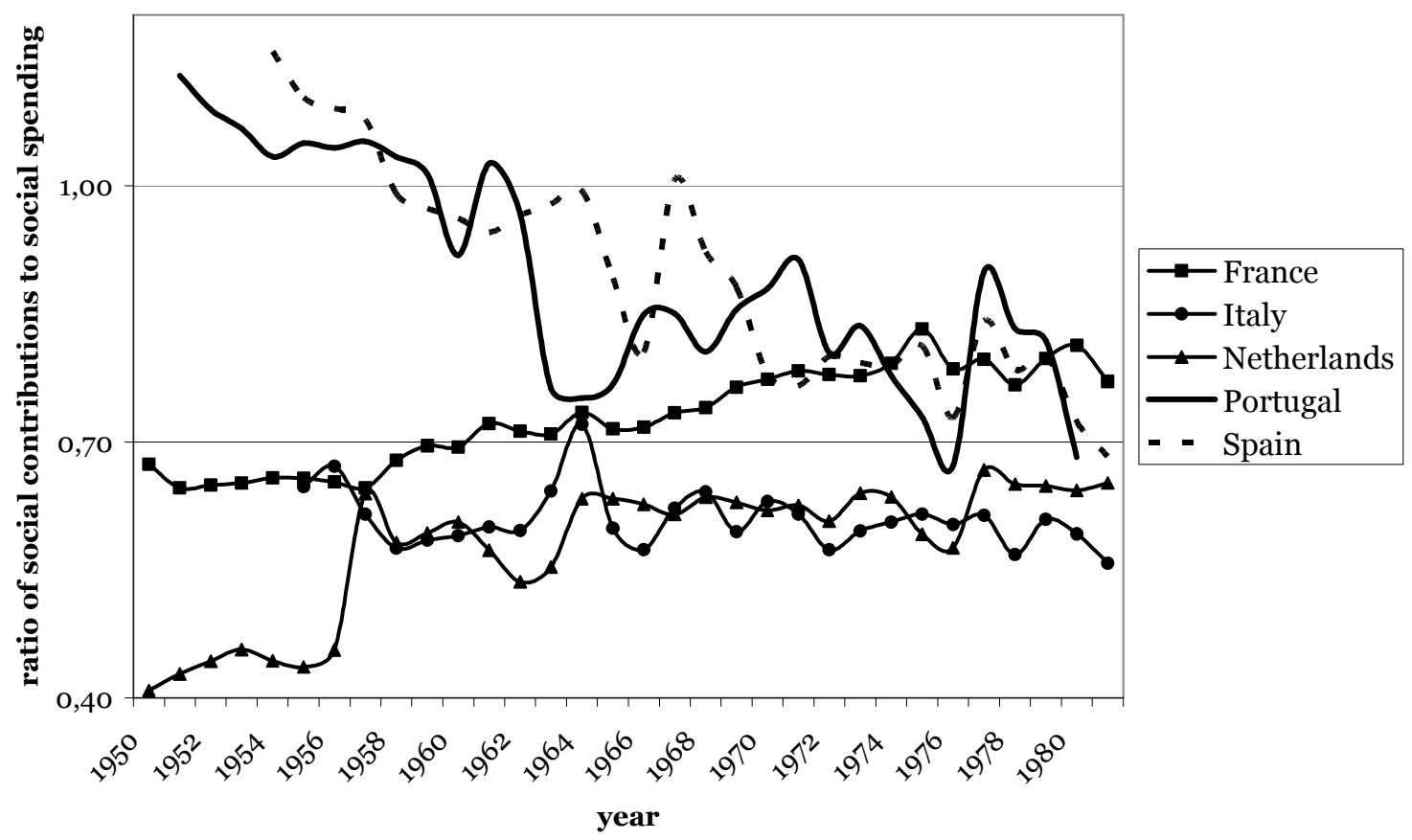

Source: see text 